\title{
EFFECTS OF MYOSMINE ON ANTIOXIDATIVE DEFENCE IN RAT LIVER
}

\author{
Rumyana SIMEONOVA ${ }^{1}$, Vessela VITCHEVA¹, Galina GORNEVA², and Mitka MITCHEVA ${ }^{1}$ \\ Laboratory of Drug Metabolism and Drug Toxicity, Department of Pharmacology, Pharmacotherapy and Toxicology, \\ Faculty of Pharmacy, Medical University ${ }^{2}$, Institute of Molecular Biology, Bulgarian Academy of Sciences ${ }^{2}$, \\ Sofia, Bulgaria
}

Received in December 2011

CrossChecked in December 2011

Accepted in March 2012

\begin{abstract}
Myosmine [3-(1-pyrrolin-2-yl) pyridine] is an alkaloid structurally similar to nicotine, which is known to induce oxidative stress. In this study we investigated the effects of myosmine on enzymatic and nonenzymatic antioxidative defence in rat liver. Wistar rats received a single i.p. injection of $19 \mathrm{mg} \mathrm{kg}^{-1}$ of myosmine and an oral dose of $190 \mathrm{mg} \mathrm{kg}^{-1}$ by gavage. Nicotine was used as a positive control. Through either route of administration, myosmine altered the hepatic function by decreasing the levels of reduced glutathione, superoxide dismutase, and glutathione peroxidase activities on one hand and by increasing malondialdehyde, catalase, and glutathione reductase activity on the other. Compared to control, both routes caused significant lipid peroxidation in the liver and altered hepatic enzymatic and non-enzymatic antioxidative defences. The pro-oxidant effects of myosmine were comparable with those of nicotine.
\end{abstract}

KEY WORDS: lipid peroxidation, oxidative stress, rodents, tobacco alkaloid

Myosmine [3-(1-pyrrolin-2-yl) pyridine] is the second tobacco alkaloid to nicotine (1). However, myosmine has a much wider distribution over a wide variety of food products such as maize, rice, wheat, cocoa, and milk in a wide range of mass fractions from $0.03 \mathrm{ng} \mathrm{g}^{-1}$ in carrots up to $6.26 \mathrm{ng} \mathrm{g}^{-1}$ in cream (2). It is therefore not surprising that myosmine has also been detected in human toenail, plasma (up to $5.5 \mathrm{ng} \mathrm{mL}^{-1}$ ), saliva (up to $4.6 \mathrm{ng} \mathrm{mL}^{-1}$ ) (3) or breast milk (4). When given orally to Wistar rats, myosmine is metabolised rapidly and completely (5). After nitrosation and/or peroxidation, myosmine bioactivates to 4-hydroxy-1(3-pyridyl)-1-butanone (HPB) and can form pyridyloxobutylated DNA adducts (6) or $N^{\prime}$ nitrosonornicotine $(\mathrm{NNN})$, which is an oesophageal carcinogen (7). In vitro experiments with calf thymus DNA have shown that myosmine is rapidly nitrosated at $\mathrm{pH} 2$ to $\mathrm{pH} 4$ and forms DNA adducts (8). Using the comet assay in human lymphocytes and upper aerodigestive tract epithelial cells, Kleinsasser et al. (9) have demonstrated dose-and time-dependent genotoxic effects of myosmine.

While there are some data about the potential genotoxic and carcinogenic effects of myosmine, little information is available about its toxicity. Organ toxicity of nicotine is known to be related to oxidative stress (10). We assume that because of its structural similarity to nicotine, myosmine might exert similar toxicity by generating reactive oxygen species (ROS).

Zwickenpflug and Tyroller (6) have suggested that because of its imine structure, myosmine seems to be more reactive than other investigated tobacco alkaloids. The authors have shown that when myosmine is mixed with hydrogen peroxide, the latter attacks the carbon nitrogen double bond of the imine 
structure, yielding oxaziranes, nitrones, or N-oxides. These metabolic intermediates might be involved in oxidative stress.

The aim of our study was to investigate the effects of myosmine on the enzymatic and non-enzymatic antioxidative defences in rat liver after a single oral and intraperitoneal (i.p.) administration.

\section{MATERIAL AND METHODS}

\section{Chemicals and enzymes}

Myosmine was synthesised at the Institute of Molecular Biology, Bulgarian Academy of Science (BAS), following the method of Brandänge and Lindblom (11). The product was found to be $99.9 \%$ pure; its identity was confirmed by comparing it with commercial myosmine using ultraviolet and infrared spectral analysis, gas chromatography, and high pressure liquid chromatography. All the other reagents used were of analytical grade. Nicotine dihydrogen ditartrate (CAS 65-31-6), 1-chloro-2,4-dinitrobenzene (CDNB), ß-nicotinamide adenine dinucleotide 2'phosphate reduced tetrasodium salt (NADPH), ethylenediaminetetraacetic acid (EDTA), L-glutathione reduced (GSH), L-glutathione oxidised (GSSG), cumene hydroperoxide, thiobarbituric acid (TBA), trichloroacetic acid (TCA), bovine serum albumin (fraction $\mathrm{V}$ ), glutathione reductase from baker's yeast (S. cerevisiae) ammonium sulfate suspension, 100 to 300 units $\mathrm{mg}^{-1}$ protein (Biuret) were purchased from Sigma-Aldrich (Taufkirchen, Germany). 2,2'-Dinitro5,5'-dithiodibenzoic acid (DTNB) was obtained from Merck (Darmstadt, Germany).

\section{Experimental animals}

Male Wistar rats weighing $(200 \pm 10) \mathrm{g}$ were housed under standard laboratory conditions at $20^{\circ} \mathrm{C}$, with 12-h alternating light/dark cycles and free access to food and water. The animals were purchased from the National Breeding Centre, Slivnitza, Bulgaria. All experiments were performed after at least one week of adaptation to this environment. All procedures were approved by the Institutional Animal Care Committee, and the principles stated in the European Convention for the Protection of Vertebrate Animals used for Experimental and other Scientific Purposes (ETS 123) (12) were strictly followed throughout the experiment.

\section{Experimental design}

Earlier studies have shown that the i.p. and oral $\mathrm{LD}_{50}$ of myosmine for rats is $190 \mathrm{mg} \mathrm{kg}^{-1}$ and $1875 \mathrm{mg} \mathrm{kg}^{-1}$, respectively (13). Before starting the experiment, we ran a pilot study to establish the doserelated effect of myosmine on animal behaviour and liver ALT, AST, and LDH (the results are not shown). A single dose of $1 / 5,1 / 10$, or $1 / 20$ of $\mathrm{LD}_{50}$ of myosmine was administered i.p. and orally to six groups of three rats per group. The dose of $1 / 20$ of $\mathrm{LD}_{50}$ did not show any statistically significant behavioural or biochemical changes. The dose of $1 / 5$ of $\mathrm{LD}_{50}$ proved very toxic ( 2 of 3 rats died after i.p. injection and 1 of 3 after oral administration) and the dose of $1 / 10$ of $\mathrm{LD}_{50}$ was well tolerated and at the same time produced significant changes in the investigated parameters. This is why we used the dose $1 / 10$ of $\mathrm{LD}_{50}$ for both routes of administration. For positive control we used nicotine ditartrate in an equitoxic dose of $1 / 10$ of $\mathrm{LD}_{50}(14)$.

The rats were then randomised into six groups with six animals in each. Group 1 were control rats treated with physiological saline i.p. (1 $\mathrm{mL} \mathrm{kg}^{-1} \mathrm{~b}$. w.). Group 2 were control rats given physiological saline via oral gavage ( $10 \mathrm{~mL} \mathrm{~kg}^{-1} \mathrm{~b}$. w.). Group 3 were rats injected with nicotine dihydrogen ditartrate i.p. $\left(1 \mathrm{mg} \mathrm{kg}^{-1} \mathrm{~b}\right.$. w.). Group 4 were rats administered nicotine dihydrogen ditartrate through oral gavage $\left(6.5 \mathrm{mg} \mathrm{kg}^{-1} \mathrm{~b}\right.$. w.). Group 5 were rats injected myosmine i.p. $\left(19 \mathrm{mg} \mathrm{kg}^{-1}\right.$ b. w.), and group 6 were rats administered myosmine through oral gavage (190 $\mathrm{mg} \mathrm{kg}^{-1}$ b. w.).

Twenty-four hours after the administration of the single dose, the animals were killed by cervical dislocation. Tissue samples were immediately transferred to ice-cold containers, weighed, and homogenised using appropriate buffers (15).

\section{Preparation of liver homogenates for lipid peroxidation (LPO) assessment}

Thiobarbituric acid reactive substances (TBARS), expressed as malondialdehyde (MDA) equivalents, were determined as a marker of lipid peroxidation. The method was described by Polizio and Peña (15). Briefly, $1 \mathrm{~mL}$ of homogenate was mixed with $1 \mathrm{~mL}$ of $25 \%$ trichloroacetic acid (TCA) and $1 \mathrm{~mL}$ of $0.67 \%$ thiobarbituric acid (TBA). Samples were then mixed thoroughly, heated in a boiling water bath for $20 \mathrm{~min}$, cooled down, and centrifuged at $4000 \mathrm{~g}$ for $20 \mathrm{~min}$. The absorbance of supernatant was measured at $535 \mathrm{~nm}$ against a blank that contained all the reagents except tissue homogenate. MDA concentration was 
calculated using a molar extinction coefficient of $1.56 \times 10^{5} \mathrm{~L} \mathrm{~mol}^{-1} \mathrm{~cm}^{-1}$ and expressed in nmol g-1 of wet tissue.

\section{Preparation of liver homogenates for reduced glutathione (GSH) assessment}

GSH was assessed by measuring non-protein sulfhydryls after precipitation of proteins with TCA, using the method described by Bump et al. (16). Briefly, tissues were homogenised in $5 \%$ TCA and then centrifuged at $4000 \mathrm{~g}$ for $20 \mathrm{~min}$. The reaction mixture contained $0.05 \mathrm{~mL}$ of supernatant, $3 \mathrm{~mL}$ of $0.05 \mathrm{~mol} \mathrm{~L}^{-1}$ phosphate buffer ( $\left.\mathrm{pH} 8\right)$, and $0.02 \mathrm{~mL}$ of DTNB reagent. The absorbance was determined at $412 \mathrm{~nm}$ and the results expressed as nmol g-1 wet tissue.

\section{Preparation of liver homogenates for antioxidant enzyme activity measurement}

Rat livers were rinsed in ice-cold physiological saline and minced with scissors. Ten-percent homogenates were prepared in $0.05 \mathrm{~mol} \mathrm{~L}^{-1}$ phosphate buffer ( $\mathrm{pH} 7.4$ ), centrifuged at $7000 \mathrm{~g}$ for 10 minutes, and the supernatants used for antioxidant enzyme analysis. The protein content of liver homogenates was measured using the method of Lowry (17) with bovine serum albumin as a standard.

\section{Catalase (CAT) activity}

CAT activity was assessed as described by Aebi (18). Briefly, $10 \mu \mathrm{L}$ of homogenate was added to $1990 \mu \mathrm{L}$ of $\mathrm{H}_{2} \mathrm{O}_{2}$ solution (containing $6.8 \mu \mathrm{L}$ of $30 \%$ $\mathrm{H}_{2} \mathrm{O}_{2}+1983.2 \mu \mathrm{L} 0.05 \mathrm{~mol} \mathrm{~L}^{-1}$ phosphate buffer, at $\mathrm{pH}$ 7.4). CAT activity was determined by measuring $\mathrm{H}_{2} \mathrm{O}_{2}$ decomposition through the decrease in absorbance at $240 \mathrm{~nm}$ for $1 \mathrm{~min}$. Enzyme activity was calculated using the molar extinction coefficient of $0.043 \mathrm{~L} \mathrm{mmol}^{-1}$ $\mathrm{cm}^{-1}$ and expressed as $\mu \mathrm{mol} \mathrm{L} \mathrm{min}^{-1} \mathrm{mg}^{-1}$ of protein.

\section{Superoxide dismutase (SOD) activity}

SOD activity was measured according to Sun and Zigman (19) with slight modifications. The incubation mixture contained $50 \mathrm{mmol} \mathrm{L}^{-1}$ carbonate buffer with $\mathrm{pH} 10.2$ at $30^{\circ} \mathrm{C}$. The reaction was started by adding epinephrine base $\left(0.001 \mathrm{~mol} \mathrm{~L}^{-1}\right.$ in $\left.0.02 \mathrm{~mol} \mathrm{~L}^{-1} \mathrm{HCl}\right)$. Epinephrine auto-oxidation was followed spectrophotometrically at $320 \mathrm{~nm}$, using the molar extinction coefficient of $4.02 \mathrm{~L} \mathrm{mmol}^{-1} \mathrm{~cm}^{-1}$. SOD activity is expressed as nanomol of epinephrine that are prevented from auto-oxidation after addition of the sample.

\section{Glutathione peroxidase (GPx) activity}

GPx activity was measured by NADPH oxidation, using a coupled reaction system consisting of reduced glutathione, glutathione reductase and cumene hydroperoxide (20). Briefly, $100 \mu \mathrm{L}$ of enzyme sample was incubated at $30^{\circ} \mathrm{C}$ for 5 min with $1.5 \mathrm{~mL}$ of $0.05 \mathrm{~mol} \mathrm{~L}^{-1}$ phosphate buffer ( $\mathrm{pH} 7.4$ ), $100 \mu \mathrm{L}$ of $1 \mathrm{mmol} \mathrm{L}{ }^{-1}$ EDTA, $50 \mu \mathrm{L}$ of $1 \mathrm{mmol} \mathrm{L}^{-1} \mathrm{GSH}, 100 \mu \mathrm{L}$ of $0.2 \mathrm{mmol} \mathrm{L}^{-1} \mathrm{NADPH}$, and $1 \mathrm{U}$ of glutathione reductase. The reaction was initiated by adding $50 \mu \mathrm{L}$ of cumene hydroperoxide $\left(1 \mathrm{mg} \mathrm{mL}^{-1}\right)$ and the rate of disappearance of NADPH over time was determined by monitoring absorbance at $340 \mathrm{~nm}$ using an extinction coefficient of $6.22 \times 10^{3} \mathrm{~L} \mathrm{~mol}^{-1} \mathrm{~cm}^{-1}$. The results are expressed in nmol min-1 $\mathrm{mg}^{-1}$ of protein.

\section{Glutathione reductase activity (GR)}

GR activity was measured spectrophotometrically at $340 \mathrm{~nm}$ according to Pinto et al. (21). We followed NADPH oxidation using the extinction coefficient of $6.22 \times 10^{3} \mathrm{~L} \mathrm{~mol}^{-1} \mathrm{~cm}^{-1}$. The incubation mixture contained $0.05 \mathrm{~mol} \mathrm{~L}^{-1}$ phosphate buffer, $\mathrm{pH} 7.4$, $2.5 \mathrm{mmol} \mathrm{L}^{-1} \mathrm{GSSG}$, and $125 \mu \mathrm{mol} \mathrm{L}^{-1} \mathrm{NADPH}$ at $30^{\circ} \mathrm{C}$. Enzyme activity is expressed in nmol $\mathrm{min}^{-1}$ $\mathrm{mg}^{-1}$ of protein.

\section{Glutathione-S-transferase (GST) activity}

GST activity was measured using CDNB as the substrate (22). The incubation mixture containing $1.6 \mathrm{~mL}$ of $0.05 \mathrm{~mol} \mathrm{~L}^{-1}$ phosphate buffer, $100 \mu \mathrm{L}$ of $1 \mathrm{mmol} \mathrm{L}{ }^{-1} \mathrm{GSH}, 100 \mu \mathrm{L}$ of $1 \mathrm{mmol} \mathrm{L}^{-1}$ EDTA, and $100 \mu \mathrm{L}$ of homogenate was incubated at $37^{\circ} \mathrm{C}$ for $15 \mathrm{~min}$. After the incubation, $100 \mu \mathrm{L}$ of $1 \mathrm{mmol} \mathrm{L}^{-1}$ $\mathrm{CDNB}$ was added and the increase in absorbance with time was recorded at $340 \mathrm{~nm}$. Enzyme activity was measured using the extinction coefficient of $9.6 \times 10^{3} \mathrm{~L} \mathrm{~mol}^{-1} \mathrm{~cm}^{-1}$ and is expressed as nanomol of CDNB-GSH conjugate per minute per milligram of protein.

\section{Statistical analysis}

The statistical analysis was performed using MedCalc (MedCalc Software bvba, Mariakerke, Belgium). The significance of the data was assessed using the non-parametric Mann-Whitney test. Values of $p \leq 0.05$ were considered statistically significant. 


\section{RESULTS}

The results are expressed as means \pm SEM for six rats per group. Figure 1 shows the levels of lipid peroxidation in the liver tissue of control animals and animals treated with myosmine and nicotine. MDA significantly increased in the myosmine and nicotinetreated groups after both i.p. injection $(+31 \%$ and $+21 \%$, respectively; $\mathrm{p} \leq 0.05$ ) and oral administration $(+29 \%$ and $+33 \%$, respectively; $\mathrm{p} \leq 0.05)$ in respect to control.

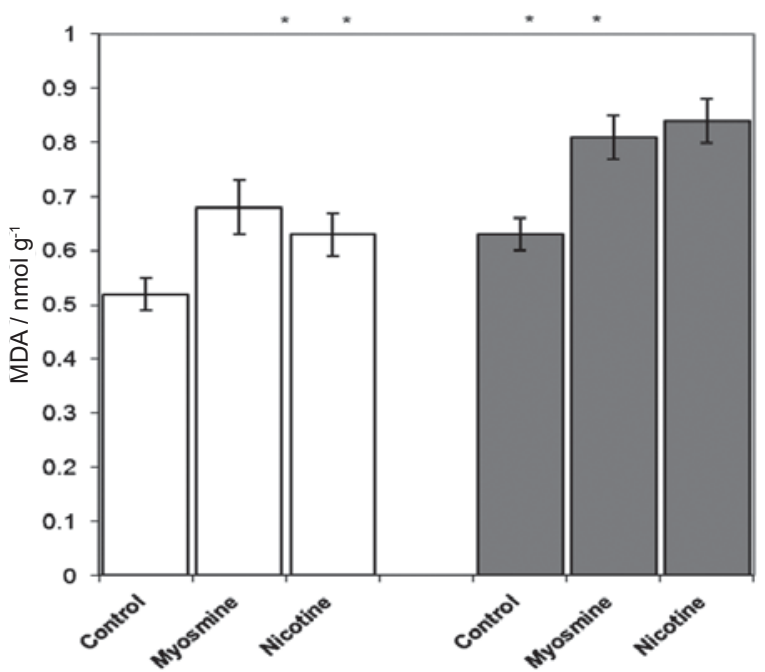

Figure $1 M D A$ concentration in rat liver 24 hafter i.p. injection

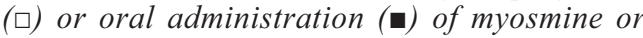
nicotine. Values are presented as the mean \pm SEM, $n=6$. *Significant difference from control values (Mann-Whitney test, $p<0.05$ )

Myosmine and nicotine treatment depleted GSH $-36 \%$ and $-14 \%$ after i.p. injection and $-23 \%$ and $-28 \%$ after oral administration, respectively (Figure 2).

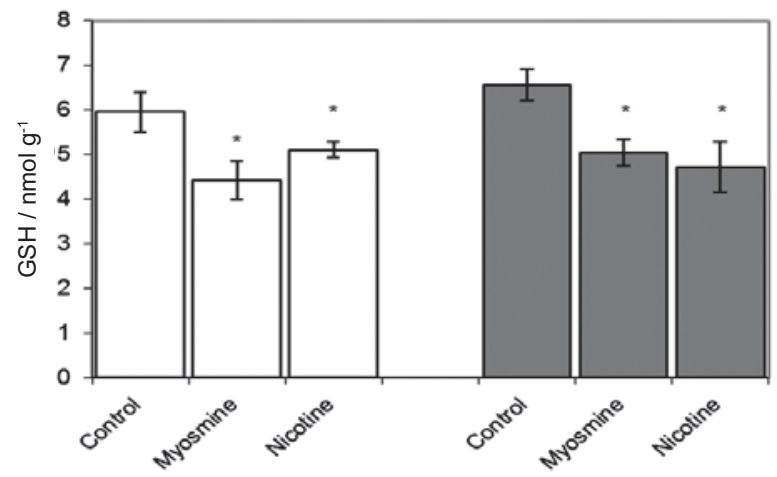

Figure 2 GSH level in rat liver 24 h after i.p. injection ( $\square$ ) or oral administration (ם) of myosmine or nicotine. Values are presented as the mean $\pm S E M, n=6$. * Significant difference from control values (MannWhitney test, $p<0.05$ )
The effects on CAT, SOD, and GPx are summarised in Figures 3-5. Significant decreases in the activity of SOD and GPx were noted with both routes of myosmine exposure and were comparable with nicotine. However, myosmine significantly increased CAT activity ( $24 \%$ after i.p. injection and $19 \%$ after oral administration; $\mathrm{p} \leq 0.05$ ), while nicotine did the opposite; it decreased CAT by $22 \%$ and $18 \%(\mathrm{p} \leq 0.05)$ after i.p. injection and oral administration, respectively.

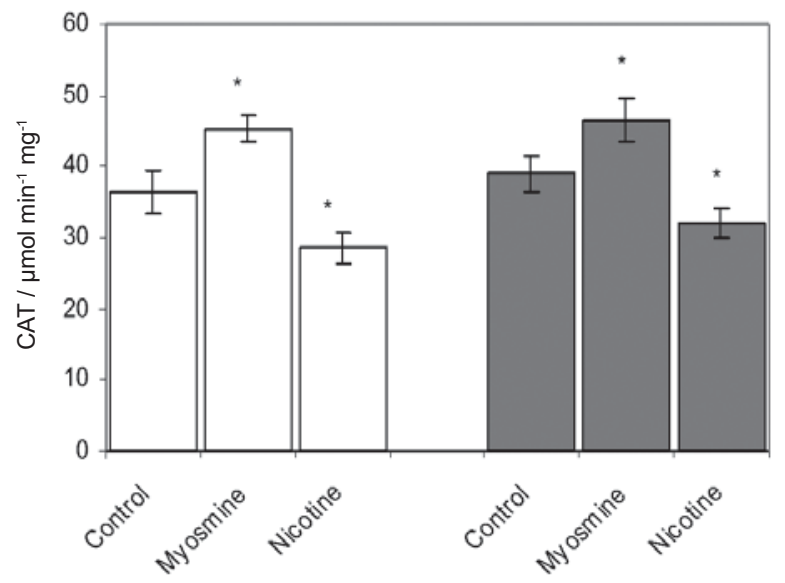

Figure 3 CAT activity in rat liver $24 \mathrm{~h}$ after i.p. injection ( $\square$ ) or oral administration (ロ) of myosmine or nicotine. Values are presented as the mean $\pm S E M, n=6$. *Significant difference from control values (MannWhitney test, $p<0.05$ )

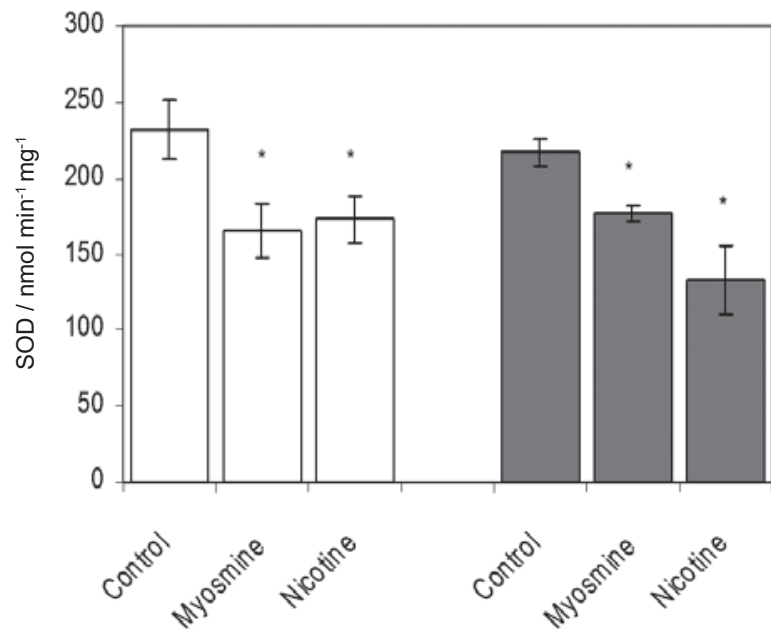

Figure 4 SOD activity in rat liver 24 h after i.p. injection () or oral administration (ロ) of myosmine or nicotine. Values are presented as the mean $\pm S E M, n=6$. *Significant difference from control values (MannWhitney test, $p<0.05$ )

Figures 6 and 7 show the activities of GR and GST after myosmine and nicotine administration. Both significantly increased GR activity through either 
route of administration, and to a similar extent, $28 \%$ and $35 \%$, respectively $(\mathrm{p} \leq 0.05)$. Neither compound induced significant changes in GST activity after either i.p. injection or oral administration.

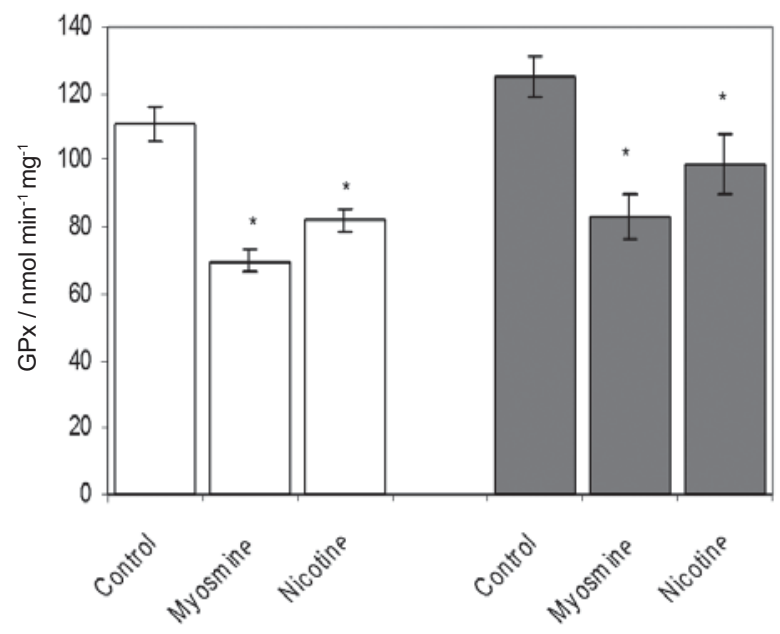

Figure 5 GPx activity in rat liver 24 h after i.p. injection (口) or oral administration (-) of myosmine or nicotine. Values are presented as the mean $\pm S E M, n=6$. *Significant difference from control values (MannWhitney test, $p<0.05$ ) difference

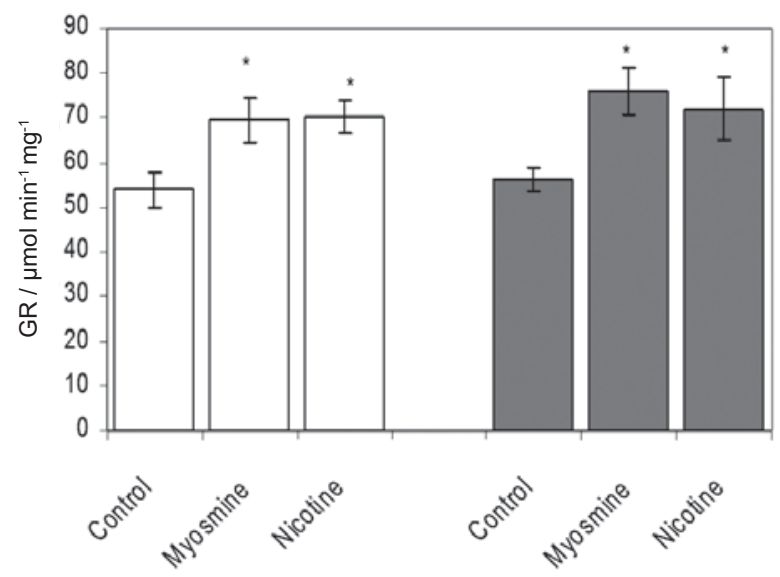

Figure 6 GR activity in rat liver 24 h after i.p. injection ( $\square$ ) or oral administration ( $\square$ ) of myosmine or nicotine. Values are presented as the mean \pm SEM, $n=6$. *Significant difference from control values (MannWhitney test, $p<0.05$ )

\section{DISCUSSION}

Oxidative stress is an imbalance between the production and scavenging of ROS and free radicals that can induce lipid peroxidation, DNA fragmentation, and protein oxidation (23). These damages result in the loss of membrane integrity, structural and functional changes in proteins and gene mutations (24). Normally, the affected cells are trying to

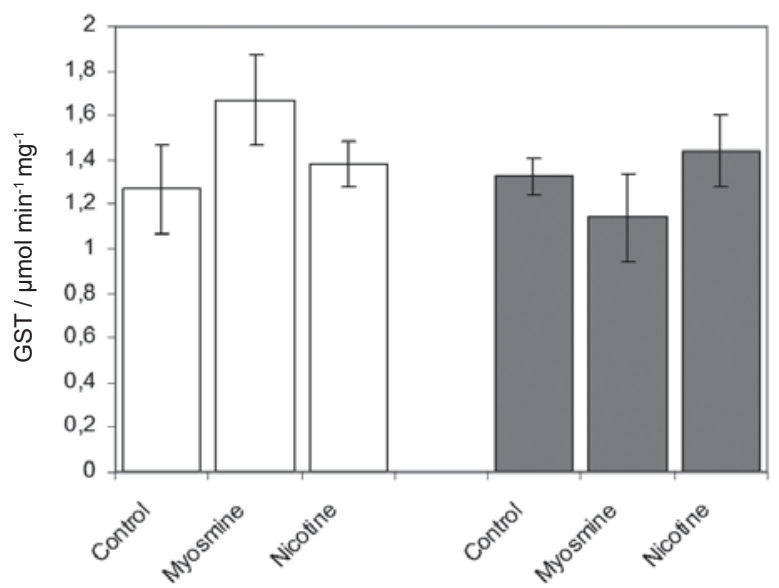

Figure 7 GST activity in rat liver 24 h after i.p. injection ( $\square$ ) or oral administration (a) of myosmine or nicotine. Values are presented as the mean $\pm S E M, n=6$.

neutralise reactive molecules by deploying their antioxidative defences that include reduced glutathione (GSH), alpha-tocopherol, ascorbic acid, and antioxidant enzymes catalase (CAT), superoxide dismutase (SOD), glutathione peroxidase (GPx), glutathione reductase (GR), and glutathione- $S$-transferase (GST).

The formation of reactive oxygen species (ROS) is stimulated by a number of xenobiotics and can result in oxidative stress and cellular injury. As myosmine is structurally similar to nicotine, which is known to induce oxidative stress (24), it is expected to act in a similar way. Its proclivity for oxidation reactions (6) may give rise to lipid peroxidation and cellular damage. In our study, a single dose of nicotine decreased GSH, SOD, CAT and GPx activities and increased MDA level and GR activity in rat liver. These results are in good agreement with the results of Sudheer et al. (26), who reported that nicotine subchronic administration resulted in significant decreases of enzymatic and non-enzymatic antioxidative defences in the liver, lung, and the circulation. Myosmine i.p. and oral treatment at equitoxic doses also led to significant increases in MDA and GR and decreased the GSH level and SOD and GPx activities. In contrast to nicotine, myosmine increased CAT activity.

In vivo metabolism of myosmine has been investigated after oral administration in female Wistar rats by Zwickenpflug et al. (5). The authors identified 3-pyridylacetic acid (3-PAA) and 4-oxo-4-(3-pyridyl) butyric acid (keto acid) as the main metabolites and 3-pyridylmethanol, 3-hydroxymyosmine and 4hydroxy-1-(3-pyridyl)-1-butanone (HPB) as minor 
metabolites. The relatively high amount of 3-PAA $(23 \%)$ suggests that myosmine undergoes a biochemical transformation in the rat stomach (27), leading to free radical formation. The increase in MDA level detected in our study may be related to the increase in free radical formation. De Zwart et al. (28) reported that lipid peroxidation produced several toxic byproducts such as MDA, which can attack cellular targets including DNA, inducing mutagenicity and carcinogenicity. The increased MDA level after myosmine treatment, might also contribute to the mutagenic and genotoxic effects of myosmine $(9,29$ $31)$. Glutathione is required to maintain the normal reduced state of cells and to counteract the adverse effects of oxidative stress. It is involved in many cellular processes including the detoxification of endogenous and exogenous compounds and can be monitored as a nonspecific indicator of cellular toxicity. The increased lipid peroxidation in myosminetreated rats can be regarded as a key event for the observed GSH depletion after i.p. and oral administration (see Figure 2). Furthermore, Zwickenpflug and Tyroller (6) suggested that myosmine peroxidation to 3-pyridylmethanol, nornicotyrine, HPB, and keto acid produced highly reactive electrophilic intermediates known as epoxides, and we believe that these electrophiles interact with the large nucleophilic pool of GSH in the liver and deplete it.

In addition to increased lipid peroxidation and decreased GSH level, myosmine significantly decreased the activities of the antioxidant enzymes SOD and GPx (see Figures 3 and 5 respectively) and increased CAT activity (see Figure 4). These enzymes act together and constitute the enzymatic antioxidative defence mechanism against reactive oxygen species (32). The SOD dismutates superoxide radicals $\left(\mathrm{O}_{2}{ }^{\circ}\right)$ into hydrogen peroxide $\left(\mathrm{H}_{2} \mathrm{O}_{2}\right)$ and $\mathrm{O}_{2}$. Catalase further detoxifies $\mathrm{H}_{2} \mathrm{O}_{2}$ into $\mathrm{H}_{2} \mathrm{O}$ and $\mathrm{O}_{2}(33)$. Glutathione peroxidase, similar to CAT, detoxifies $\mathrm{H}_{2} \mathrm{O}_{2}$. Lower SOD and GPx activities in our study could be attributed to several mechanisms. The first is their overconsumption in inactivating the reactive intermediates generated during the metabolism of myosmine. The second is that oxidative stress could inactivate enzyme proteins through these intermediates or could be a consequence of lower de novo synthesis of enzyme proteins. The increased hepatic CAT activity may be a compensatory mechanism to get rid of excess peroxides due to low GPx activity. The third is that the activation of myosmine by peroxidative or nitrosative mechanisms could lead to pyridyloxobutylation of proteins, DNA, and RNA (6, 8,30 ) and could compromise their functioning.

The significant increase in GR (see Figure 6) could be attributed to increased GSSG production, which we have not measured in this study but which is reasonable to assume (23).

Our study confirms that single i.p. and oral administration of myosmine significantly increases lipid peroxidation and compromises the enzymatic and non-enzymatic antioxidative defence systems. Its pro-oxidant effects are comparable with those of nicotine.

\section{Acknowledgements}

This work was supported by the National Fund for Scientific Research grant no. TK-L-1608/06 of the Bulgarian Ministry of Education and Sciences. We wish to thank Professor Elmar Richter for his continuous interest in this work and for helpful discussions, Dr Wolfgang Zwickenpflug for the HPLC analysis of myosmine, and Rumyana Gugova for its synthesis.

\section{REFERENCES}

1. Wenusch A, Schöller R. [Beitrag zur Kenntnis der Zusammensetzung des Zigarrenrauches, in German]. Fachl Mitt Österr Tabakregie 1933;2:15-9.

2. Tyroller S, Zwickenpflug W, Richter E. New sources of dietary myosmine uptake from cereals, fruits, vegetables and milk. J Agric Food Chem 2002;50:4909-15.

3. Schütte-Borkovec K, Heppel CW, Heling A-K, Richter E. Analysis of myosmine, cotinine and nicotine in human toenail, plasma and saliva. Biomarkers 2009;14:278-84.

4. Maier M, Schulze A, Richter E. Biomonitoring of myosmine in human milk and saliva. Toxicol Lett 2005;158:S201-2.

5. Zwickenpflug W, Tyroller S, Richter E. Metabolism of myosmine in Wistar rats. Drug Metab Dispos 2005;33:164856.

6. Zwickenpflug W, Tyroller S. Reaction of the tobacco alkaloid myosmine with hydrogen peroxide. Chem Res Toxicol 2006;19:150-5.

7. Zwickenpflug W. $N$-nitrosation of myosmine yields HPB (4-hydroxy-1-(3-pyridyl)-1-butanone) and NNN ( $N$ nitrosonornicotine). J Agric Food Chem 2000;48:392-4.

8. Wilp J, Zwickenpflug W, Richter E. Nitrosation of dietary myosmine as risk factor of human cancer. Food Chem Toxicol 2002;40:1223-8.

9. Kleinsasser NH, Wallner BC, Harréus UA, Zwickenpflug W, Richter E. Genotoxic effects of myosmine in human lymphocytes and upper aerodigestive tract epithelial cells. Toxicology 2003;192:171-7.

10. Vijayan V, Helen A. Protective activity of Bacopa monieara Linn. on nicotine-induced toxicity in mice. Phytother Res 2007;21:378-81. 
11. Brandänge $\mathrm{S}$, Lindblom L. $N$-Vinyl as N-H protection group. A convenient synthesis of myosmine. Acta Chem Scand Ser B 1976;30:93.

12. Council of Europe. European Convention for the Protection of Vertebrate Animals used for Experimental and other Scientific Purposes. CETS No. 123, 1991 [displayed 21 February 2012]. Available at http://conventions.coe.int/ $\mathrm{Tr}$ e a t y / C o m m u n / Q u e Vou 1 e z Vou s asp? $\mathrm{NT}=123 \& \mathrm{CM}=1 \& \mathrm{CL}=\mathrm{ENG}$

13. Ambrose AM, DeEds F. Some comparative observations on $l$-nicotine and myosmine. Proc Soc Exp Biol Med 1946;63:423-4.

14. Safety Data Sheet for Nicotine Bitartrate Dihydrate. Revision on 13/08/2008. [displayed 21 February 2012]. Available at http://www.nicobrand.com/files/Nicotine_Bitartrate Dihydrate MSDS.pdf

15. Polizio AH, Peña C. Effects of angiotensin II type 1 receptor blockade on the oxidative stress in spontaneously hypertensive rat tissues. Regul Pept 2005;128:1-5.

16. Bump EA, Taylor YC, Brown MJ. Role of glutathione in the hypoxic cell cytotoxicity of misonidazole. Cancer Res 1983;43:997-1002.

17. Lowry OH, Rosebrough NJ, Farr AL, Randall RJ. Protein measurement with the Folin phenol reagent. J Biol Chem 1951;193:265-75.

18. Aebi H. Catalase. In: Bergmeyer HU, editor. Methods of enzymatic analysis [Methoden der enzymatischen Analyse, in German]. Weinheim: Verlag Chemie; 1974. p. 673-84.

19. Sun M, Zigman S. An improved spectrophotometric assay for superoxide dismutase based on epinephrine autooxidation. Anal Biochem 1978;90:81-9.

20. Tappel AL. Glutathione peroxidase and hydroperoxides. Methods Enzymol 1978;52:506-13.

21. Pinto MC, Mata AM, Lopez-Barea J. Reversible inactivation of Saccharomyces cerevisiae glutathione reductase under reducing conditions. Arch Biochem Biophys 1984;228:112.

22. Habig WH, Pabst MJ, Jakoby WB. Glutathione S-transferases. The first enzymatic step in mercapturic acid formation. J Biol Chem 1974;249:7130-9.

23. Nencini C, Giorgi G, Micheli L. Protective effect of silymarin on oxidative stress in rat brain. Phytomedicine 2007;14:12935 .
24. Reddy BV, Sundari JS, Balamurugan E, Menon VP. Prevention of nicotine and streptozotocin treatment induced circulatory oxidative stress by bis-1,7-(2-hydroxyphenyl)hepta-1,6-diene-3,5-dione in diabetic rats. Mol Cell Biochem 2009;331:127-33.

25. Zwickenpflug W, Meger M, Richter E. Occurrence of the tobacco alkaloid myosmine in nuts and nut products of Arachus hypogaea and Corylus avellana. J Agric Food Chem 1998;46:2703-6.

26. Sudheer AR, Muthukumaran S, Devipriya N, Devaraj H, Menon VP. Influence of ferulic acid on nicotine-induced lipid peroxidation, DNA damage and inflammation in experimental rats as compared to $\mathrm{N}$-acetylcysteine. Toxicology 2008;243:317-9.

27. Glas S, Tyroller S, Zwickenpflug W, Steiner K, Kiefer G, Richter E. Tissue distribution and excretion of myosmine after i.v. administration to Long-Evans rats using quantitative whole-body autoradiography. Arch Toxicol 2007;81:15161.

28. de Zwart LL, Meerman JHN, Commandeur JNM, Vermeulen NPE. Biomarkers of free radical damage: applications in experimental animals and in humans. Free Radic Biol Med 1999;26:202-26.

29. Richter E, Schlöbe D, Hölzle D, Wilp J. Comparative DNA and hemoglobin adduct formation by dietary myosmine and $N$ '-nitrosonornicotine in rats. Naunyn-Schmiedeberg's Arch Pharmacol 2002;365(Suppl.1):R140.

30. Vogt S, Fuchs K, Richter E. Genotoxic effects of myosmine in a human esophageal adenocarcinoma cell line. Toxicology 2006;222:71-9.

31. Havla JB, Hill CE, Abdel-Rahman SZ, Richter E. Evaluation of the mutagenic effects of myosmine in human lymphocytes using the HPRT gene mutation assay. Food Chem Toxicol 2009;47:237-41.

32. Bhattacharjee R, Sil PC. The protein fraction of Phyllanthus niruri plays a protective role against acetaminophen induced hepatic disorder via its antioxidant properties. Phytother Res 2006;20:595-601.

33. Fridovich I. Superoxide dismutases. Adv Enzymol Relat Areas Mol Biol 1986;58:61-97. 


\section{Sažetak}

\section{DJELOVANJE MIOZMINA NA ANTIOKSIDATIVNE SUSTAVE U JETRI ŠTAKORA}

Miozmin (3-(1-pirolin-2-il)piridin) alkaloid je strukturno sličan nikotinu, za koji se zna da potiče oksidativni stres. Istražili smo djelovanje miozmina na enzimske i neenzimske antioksidativne sustave u jetri štakora. Wistar štakori primili su jednokratno pokusni spoj intraperitonealno u dozi od $19 \mathrm{mg} \mathrm{kg}^{-1}$, odnosno na usta u dozi od $190 \mathrm{mg} \mathrm{kg}^{-1}$. Za pozitivnu kontrolu rabili smo nikotin.

Nakon primjene, bez obzira na put, zamijećena je promjena u jetrenoj funkciji u obliku pada razina glutationa, aktivnosti superoksid dismutaze i glutation peroksidaze te rasta razina malondialdehida, aktivnosti katalaze i glutation reduktaze. Ovi nalazi upućuju na to da intraperitonealna i oralna primjena miozmina dovode do značajne lipidne peroksidacije u jetrenome tkivu te promjena u enzimskoj i neenzimskoj zaštiti jetre. Prooksidativno djelovanje miozmina pokazalo se sličnim onomu nikotina.

KLJUČNE RIJEČI: duhanski alkaloid, glodavci, lipidna peroksidacija, oksidativni stres

\section{CORRESPONDING AUTHOR:}

Vessela Vitcheva

Department of Pharmacology, Pharmacotherapy

and Toxicology

Faculty of Pharmacy, Medical University

2 Dunav St., 1000 Sofia, Bulgaria

E-mail: vesselavitcheva@yahoo.com 